\title{
PENGARUH MASA SIMPAN KRIM SANTAN TERHADAP TINGKAT PENERIMAAN PANELIS
}

\section{The effect of coconut cream shelf life on the panelist acceptance}

\author{
Asriani I. Laboko* \\ Program Studi Teknologi Hasil Pertanian, Fakultas Pertanian, Universitas Ichsan Gorontalo, Indonesia \\ Doi: $10.37195 / j a c . v 2 i 1.95$
}

\begin{tabular}{l} 
*KORESPONDENSI \\
\hline Telepon: +62-853-4170-1787 \\
E-mail: asrianilaboko@yahoo.co.id \\
JEJAK PENGIRIMAN
\end{tabular}

Diterima: 4 Jan 2020

Revisi Akhir: 28 Feb 2020

Disetujui: 28 Mar 2020

\section{KEYWORDS}

Coconut, Storage, Coconut milk

KATA KUNCI

Kelapa, Penyimpanan, Santan

\begin{abstract}
Coconut (Nyiur) is a tall palm tree beach, a quite old plant, that mostly spread throughout the tropics, and at the beginning of the Christian era it was well known and utilized by people in daily life and subsequently people had been traded as merchandise to various places, both abroad such as India, Sri Lanka, or in domestically (Indonesia). This study aimed to determine the level of coconut milk cream storage on the aroma, color, and texture. This research was conducted by an experiment with 3 treatments and 3 replications. S1 = $15 \mathrm{~g}$ salt : $500 \mathrm{~g}$ coconut grated, $S 2=20 \mathrm{~g}$ salt $: 500 \mathrm{~g}$ coconut grated, $S 3=25 \mathrm{~g}$ salt $: 500 \mathrm{~g}$ coconut grated. These treatments were tested by organoleptic tests which included aroma, color, and texture with 25 panelists. The results showed that at 3 weeks of storage, those treatments had not been decay. The more salt adding to coconut milk cream, the slower the process of decay, which can be seen from the panelist preferred level and the treatment preferred by the panelists, as well as resistant to decay. It was showed by S2 treatment ( $20 \mathrm{~g}$ salt : $500 \mathrm{~g}$ coconut grated).
\end{abstract}

Kelapa (nyiur) merupakan tumbuhan palma pantai yang pohonnya tinggi, tanaman yang berusia cukup tua, yang banyak tersebar di seluruh daerah tropika, dan pada permulaan zaman Masehi sudah dikenal dan dimanfaatkan orang dalam kehidupan sehari-hari dan selanjutnya telah diusahakan orang sebagai barang dagang ke berbagai tempat, baik ke luar negeri seperti India, Sri Langka, ataupun di kepulauan nusantara (Indonesia). Tujuan penelitian ini adalah untuk mengetahui tingkat penyimpanan terhadap krim santan dari segi aroma, warna, dan tekstur. Metode penelitian ini adalah percobaan dengan 3 perlakuan 3 kali ulangan. $\mathrm{S} 1=15 \mathrm{~g}$ garam $: 500 \mathrm{~g}$ parutan kelapa, $\mathrm{S} 2=20 \mathrm{~g}$ garam $: 500 \mathrm{~g}$ parutan kelapa, S3 = $25 \mathrm{~g}$ garam : $500 \mathrm{~g}$ parutan kelapa. Ketiga perlakuan ini menerapkan uji organoleptik yang meliputi aroma, warna, dan tekstur dengan 25 jumlah panelis. Hasil penelitian menujukkan bahwa, pada proses penyimpanan 3 minggu belum mengalami proses kerusakan. Makin meningkat proses penambahan garam pada santan, maka proses kerusakan makin lambat, yang dapat dilihat dari tingkat kesukaan panelis dan perlakuan yang disukai panelis serta tahan akan kerusakan, yang ditunjukkan oleh perlakuan S2 (rasio garam dan parutan kelapa 20 gram : 500 gram).

\section{PENDAHULUAN}

Indonesia merupakan Negara yang memiliki potensi yang cukup besar untuk pertumbuhan kelapa, dimana tanaman kelapa (Cocos nucifera L.) yang cukup meningkat dan mempunyai manfaat sangat besar dalam kehidupan manusia sehari-hari yang sering 
dimanfaatkan mulai dari akar, batang sampai ke pucuk. Tanaman kelapa dapat membantu perekonomian masyarakat dan Negara. Salah satu bagian yang memiliki manfaat adalah buah kelapa yang dapat diolah menjadi berbagai jenis olahan dan beberapa produk. Santan dan minyak diolah dari daging buah kelapa sedangkan arang aktif berasal dari batok kelapa yang bisa dimanfaatkan oleh masyarakat (Sidik, Fatimah, \& Sangi, 2013).

Salah satu hasil penelitian Djatmiko, Goutara, dan Irawadi (1981) menyatakan bahwa, salah satu tanaman yang sangat penting bagi kehidupan manusia adalah kelapa dan bisa menghasikan berbagai macam produk olahan. Komposisi buah kelapa tua terdiri dari, $28 \%$ daging buah, $12 \%$ tempurung, $25 \%$ air dan buah, 35\% sabut dan tingkat kematangan daging buah kelapa bervariasi. Buah kelapa yang tua memiliki kandungan lemak tinggi. Salah satu olahan dari kelapa adalah santan.

Indonesia merupakan salah satu Negara yang memiliki minat tinggi terhadap produk makanan berbahan tambahan santan. Sebagian besar penggunaan santan bertujuan untuk menambah cita rasa gurih berbagai macam makanan. Ibu rumah tangga selama ini banyak memanfaatkan santan sebagai pemberi cita rasa masakan dan berbagai jenis minuman. Sejak dahulu minuman santan sudah dikenal oleh masyarakat seperti, cendol, bajigur, es doger, dan beberapa minuman yang berbahan baku dari santan. Santan merupakan bahan pangan yang sering digunakan untuk meningkatkan aroma masakan adalah santan, karena santan memiliki aroma khas yang tidak dimiliki oleh bahan lainnya. Santan segar merupakan bahan pangan yang mudah rusak dan cepat mengalami ketengikan karena hanya dapat bertahan pada suhu ruang selama 24 jam. Hal ini sesuai pendapat Tangsuphoom dan Coupland (2009) yang menyatakan bahwa santan merupakan emulsi lemak dalam air dengan ukuran partikel lebih besar dari satu mikron dan berwarna putih susu.

Pengolahan kelapa dimulai dari akar, batang, daun, buah bahkan dari daun kelapa pada penelitian ini bagian buah kelapa yang diolah sebagai bahan pangan, yaitu krim santan yang memiliki kandungan yang baik. Tujuan dari penelitian ini adalah untuk melihat daya simpan produk santan dengan penambahan garam dilihat dari segi organoleptik yang terdiri dari, aroma, warna dan tekstur.

\section{BAHAN DAN METODE}

\section{Bahan}

Bahan yang digunakan pada penelitian ini adalah buah kelapa berasal dari para petani yang berasal dari Daerah Kecamatan Tilamuta Kabupaten Boalemo Provinsi Gorontalo, garam didapatkan dari pasar tradisional, dan air.

\section{Desain Penelitian}

Jenis penelitian yang dilakukan merupakan penelitian eksperimental dengan pengujian organoleptik metode hedonik meliputi aroma, warna dan tekstur menggunakan panelis sebanyak 25 orang. Skor penilaian adalah 1 (sangat tidak suka), 2 (tidak suka), 3 (agak suka), 4 ( suka) dan 5 (sangat suka).

Perlakuan yang dilakukan pada penelitian ini adalah:

S1 = 15 g garam $: 500$ g parutan kelapa

$\mathrm{S} 2=20 \mathrm{~g}$ garam $: 500 \mathrm{~g}$ parutan kelapa

S3 $=25$ g garam : 500 g parutan kelapa

\section{Persiapan Bahan Baku}

Bahan baku yang digunakan adalah buah kelapa yang sudah matang berasal dari para petani. Tingkat kematangan dilihat dari bagian kulit buah kelapa dengan waran kecoklatan. Selanjutnya dilakukan proses pemisahan kulit kelapa dan bagian sabut kelapa.

\section{Pembelahan Buah Kelapa}

Buah kelapa yang sudah dibersihkan dari kulit dan sabutnya kemudian dilakukan proses pembelahan, untuk mengeluarkan air kelapa dan bagian tempurung, bagian dalam/daging kelapa yang digunakan.

\section{Penggilingan/Pemarutan Daging Kelapa}

Penggilingan/pemarutan daging kelapa dilakukan dengan menggunakan mesin pemarut kelapa dengan kecepatan tinggi. Pemarutan bertujuan untuk memperkecil partikel dan mempermudah proses pemerasan.

\section{Pemerasan/Penambahan Air}

Hasil parutan kelapa sebanyak $500 \mathrm{~g}$ ditambahkan air sebanyak $600 \mathrm{ml}$, untuk mempermudah keluarnya santan pada kelapa. 
Pemerasan dilakukan dua kali dengan penambahan air awal $300 \mathrm{ml}$ dan penambahan air kedua $300 \mathrm{ml}$.

\section{Penambahan Garam}

Selanjutnya hasil pemerasan didiamkan lalu dilakukan penambahan garam dengan perlakuan, $\mathrm{S} 1=15 \mathrm{~g}, \mathrm{~S} 2=20 \mathrm{~g}$ dan $\mathrm{S} 3=25 \mathrm{~g}$ kemudian diaduk dan didiamkan selama 10-15 menit untuk memisahkan skim dan air santan dan mempermudah pengambilan krim dan skim.

\section{Pemanasan/Pemasakan}

Skim/krim dipanaskan pada temperatur yang mendekati titik didih, selanjutnya dimasukkan dalam keadaan panas ke dalam botol atau kaleng kemasan dan kemudian disegel dan santan siap dikonsumsi.

\section{Penyimpanan}

Setelah dilakukan proses pemasakan maka langkah selanjutnya adalah proses penyimpanan, untuk melihat daya tahan simpan dari krim santan dengan waktu yang telah di tentukan yaitu selama 3 minggu, penyimpanan diterapkan pada satu versi yaitu suhu dingin. Proses penilaian minggu pertama untuk pemeriksaan dengan memberikan sampel kepada panelis dan panelis akan memberikan sekor yang sudah ditentukan, selanjutnya di ikuti minggu kedua, dan minggu ketiga.

\section{HASIL DAN PEMBAHASAN}

\section{Aroma}

Aroma memiliki peran yang sangat penting dalam penentuan penerimaan makanan dari sensori makanan bermutu. Sebelum dikonsumsi aroma makanan tersebut akan sangat mempengaruhi nafsu makanan seseorang. Hidung merupakan salah satu organ penciuman yang sangat kuat untuk menerima sensasi aroma (Moulton, 1982).

Gbr. 1 menunjukkan bahwa, krim santan yang dihasilkan dengan penambahan garam pada 1 minggu menghasilkan aroma yang agak disukai pada perlakuan S2. Penambahan garam dengan rasio 20 gram mempertahankan aroma khas santan sehingga semakin disukai oleh panelis, perlakuan S2 yang disukai panelis

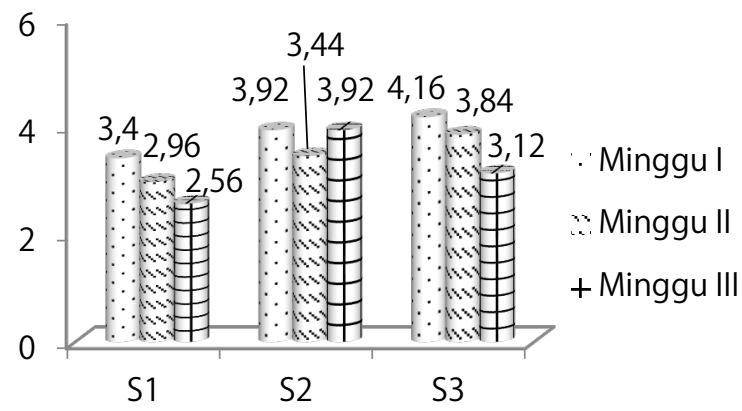

Gbr. 1. Hasil uji organoleptik terhadap aroma krim santan

karena garam yang digunakan dapat menyebabkan kebanyakan mikroorganisme tidak dapat hidup, sehingga dapat mengawetkan krim santan. Krim santan yang awet dapat membuat aromanya disukai oleh panelis. Hal ini sesuai dengan pernyataan Ketaren (2008), bahwa banyak di antara makanan berlemak terdapat mikroba yang menghasilkan enzim dapat memecah protein, sehingga menghasilkan bau tengik dan rasa tidak enak. Penguraian persenyawaan protein, lemak, dan karbohidrat menghasilkan asam propionat, butirat, laktat dan asam-asam menguap lainnya. Secara alami bau tengik terdapat pada minyak juga terjadi karena pembentukan asam-asam yang berantai sangat pendek sebagai hasil penguraian pada kerusakan minyak yang dapat mempengaruhi aroma minyak yang dihasilkan.

\section{Warna}

Warna merupakan salah satu daya tarik yang diberikan oleh produk, sehingga memberikan minat ingin memiliki produk yang visualisasi indera penglihatan (mata) (Marshall, 2014 dalam Simamora \& Rossi, 2017).

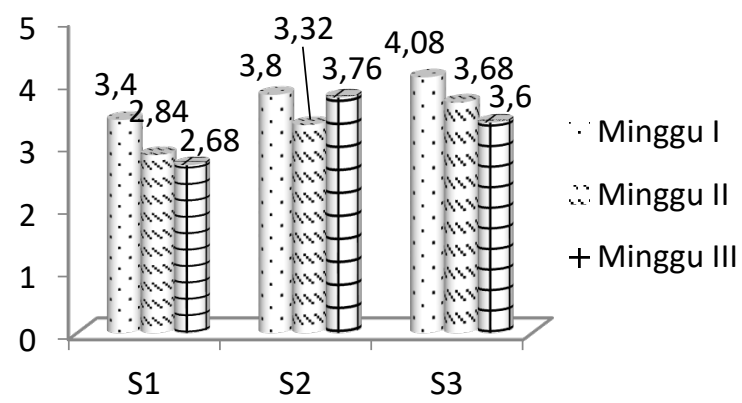

Gbr. 2. Hasil uji organoleptik terhadap warna krim santan 
Gbr. 2 menunjukkan krim santan yang dihasilkan dengan penambahan garam menghasilkan warna santan disukai panelis terdapat pada perlakuan S3, semakin meningkat penambahan garam pada santan maka warna akan semakin cerah (baik) ini dikarena santan belum mengalami kerusakan atau perubahan warna dan belum terjadi kerusakan pigmen-pigmen yang terdapat pada krim santan.

Mikroorganisme akan mati karena tinggi kadar garam. Hal ini disebabkan karena mikroorganisme tidak tahan terhadap garam. Mikroorganisme yang tahan garam dapat tumbuh karena kondisi selektif memungkinkan. Pada kondisi tertentu penambahan garam berfungsi mengawetkan karena kadar garam yang tinggi menghasilkan tekanan osmotik yang tinggi dan aktivitas air rendah. Mikroorganisme tidak dapat hidup karena memiliki kondisi ekstrim. Untuk menghasilkan produk fermentasi dan enzimatis biasanya hanya menggunakan penambahan garam (Estiasih \& Ahmadi, 2011).

Warna putih pada pasta santan diduga disebabkan oleh kandungan lemak dan protein pada daging buah kelapa. Kandungan lemak dan protein pasta santan yang tertinggi terdapat pada santan dari buah dengan tingkat kematangan tua sedang (setelah kelapa melewati umur 12 bulan). Hal ini disebabkan semakin tua buah kelapa kandungan lemak dan protein pada daging buah kelapa semakin meningkat akan tetapi pada tingkat kematangan buah sedang, kandungan lemak dan protein pada daging buah menurun. Sesuai pendapat Cahya dan Susanto (2014) bahwa, penyebab menurunnya kandungan lemak dan protein pada daging buah dikarenakan adanya penyerapan nutrisi oleh lembaga buah kelapa.

\section{Tekstur}

Tauferova et al. (2015) menyatakan bahwa, tekstur makanan ini digambarkan sebagai fungsional dan sensori manifestasi dari sifat permukaan mekanik dan struktural dideteksi melalui kinestetik, penglihatan, pendengaran dan sentuhan. Atribut sensorik makanan ini dikonseptualisasikan melalui berbagai cara seperti ketebalan, kerenyahan, ketegasan dan kehalusan.

Gambar 3 menunjukkan bahwa tekstur pada krim santan kelapa yang paling disukai adalah perlakuan S2, dilihat dari lama penyimpanan bahwa perlakuan yang paling disukai dengan lama penyimpanan terdapat pada 2 minggu. Hal ini disebabkan oleh pememecah emulsi santan dengan pengaturan kelarutan protein di dalam garam. Adanya penambahan garam di dalam cairan santan akan mempermudah pelarutan protein (selting in), dengan seiringnya waktu meningkatnya kosentrasi garam akan menurunkan kelarutan protein. Hal ini sesuai dengan pernyataan Ismunandar (n.d.), bahwa lemak berfungsi sebagai pemberi tekstur halus pada bahan pangan serta berkontribusi pada rasa memberi efek sinergis dengan flavor yang ditambahkan dapat memperbaiki penampilan suatu produk.

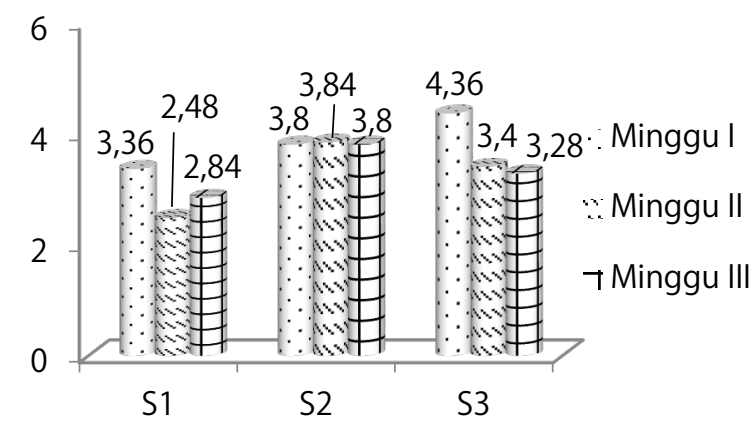

Gbr. 3. Hasil uji organoleptik terhadap tekstur krim santan

\section{KESIMPULAN}

Kesimpulan yang diperoleh dari penelitian ini adalah bahwa sesuai tingkat kesukaan panelis maka, makin meningkat penambahan garam maka makin lama penyimpanan krim santan, dengan lama waktu penyimpanan 3 minggu dan belum terjadi proses kerusakan pada krim santan dan perlakuan yang disukai panelis adalah perlakuan S2 yaitu rasio garam dan parutan kelapa 20 gram : 500 gram.

\section{PENGHARGAAN}

Ucapan terima kasih kepada ketua Lembaga Penelitian Universitas Ichsan Gorontalo yang telah memberikan bantuan dana.

\section{DAFTAR PUSTAKA}

Cahya, F., \& Susanto, W. H. (2014). Pengaruh pohon pasca sadap dan kematangan buah kelapa terhadap sifat fisik, kimia, organoleptik pasta santan. Jurnal Pangan 
dan Agroindustri, 2(4), 249-258.

Djatmiko, B., Goutara, \& Irawadi. (1981). Pengolahan Kelapa I. Bogor: Jurusan Teknologi Industri, Fakultas Teknologi Pertanian, IPB.

Estiasih, T., \& Ahmadi, K. G. S. (2011). Teknologi Pengolahan Pangan. Jakarta: Bumi Aksara.

Ismunandar. (n.d.). Dibalik lembutnya es krim. Retrieved March 23, 2020, from http://www.kimianet.lipi.go.id/utama.cgi?c etakartikel\&1102121768

Ketaren, S. (2008). Pengantar Teknologi Minyak dan Lemak Pangan (Cetakan Pertama). Jakarta: UI-Press.

Moulton, D. G. (1982). Sensory Basis and Perception of Flavor. In I. D. Morton \& A. J. MacLeod (Eds.), Food Flavor: Part A. Introduction (pp. 1-34). Amsterdam, Oxford: Elsevier Scientific.
Simamora, D., \& Rossi, E. (2017). Penambahan pektin dalam pembuatan selai lembaran buah Pedada (Sonneratia caseolaris). JOM Fakultas Pertanian, 4(2), 1-14.

Sidik, S. L., Fatimah, F., \& Sangi, M. S. (2013). Pengaruh penambahan emulsifier dan stabilizer terhadap kualitas santan kelap. Jurnal MIPA Unsrat Online, 2(2), 79-83.

Tangsuphoom, N., \& Coupland, J. N. (2009). Effect of thermal treatments on the properties of coconut milk emulsions prepared with surface-active stabilizers. Food Hydrocolloid, 23(7), 1792-1800.

Tauferova, A., Tremlova, B., Bednar, J., Golian, J., Zidek, R., \& Vietoris, V. (2015). Determination of ketchup sensory texture acceptability and examination of determining factors as a basis for product optimization. International Journal of Food Properties, 18(3), 660-669. 